\title{
NATURE OF ANAEMIA IN RHEUMATOID ARTHRITIS IV. EFFECTS OF THE INTRAVENOUS ADMINISTRATION OF SACCHARATED OXIDE OF IRON
}

\author{
BY
}

\author{
J. RICHMOND, L. M. H. ROY, D. L. GARDNER, W. R. M. ALEXANDER, \\ AND J. J. R. DUTHIE \\ From the Rheumatic Unit, Northern General Hospital, Edinburgh
}

In previous communications the characteristics of the anaemia and abnormalities in the metabolism of iron in patients suffering from rheumatoid arthritis have been described (Roy, Alexander, and Duthie, 1955; Richmond, Gardner, Roy, and Duthie, 1956). The most important results of these investigations may be briefly summarized: the existence of moderate hypochromia of the red cells was confirmed; there was a significant degree of hypoferraemia, but unlike the finding in simple iron deficiency anaemia, the total iron binding capacity of the plasma was normal; no evidence of impaired absorption of iron from the gut was obtained, an observation substantiated by Jeffrey, Freundlich, Jackson, and Watson (1955) using radioactive iron; the rate of removal of saccharated oxide of iron (S.O.I.) from the plasma after intravenous administration was more rapid in patients suffering from rheumatoid arthritis than in healthy individuals. In a study of 61 patients, stainable iron (Prussian blue method) was absent from the marrow, or present only in very small quantities, in 49 per cent. of cases. The normoblast count in the marrow varied directly with the haemoglobin level in the blood, suggesting a failure on the part of the marrow to respond to the anaemia. A highly significant correlation was found to exist between the degree of anaemia and the erythrocyte sedimentation rate. No relationship could be demonstrated between the haemoglobin level $(\mathrm{Hb})$, red cell count (R.B.C.), mean corpuscular haemoglobin concentration (M.C.H.C.), or plasma iron level, and the iron content of the bone marrow.

Alexander, Richmond, Roy, and Duthie (1956), using the Ashby technique of differential agglutination, showed that erythrocytes from healthy donors were eliminated from the circulation with abnormal rapidity in patients with rheumatoid arthritis, although erythrocytes from rheumatoid donors survived rather longer in rheumatoid recipients. Despite absence of the usual signs of blood destruction (reticulocytosis, increased amounts of bilirubin in the serum, and urobilinogen in the urine), these findings suggested that a haemolytic process was one factor in the causation of the anaemia. This haemolytic process appeared to be uninfluenced by. the administration of corticotrophin in doses sufficient to suppress the clinical signs of the disease

\section{Use of Saccharated Oxide of Iron}

The role of iron in the aetiology of the anaemia of rheumatoid arthritis has proved difficult to evaluate Several workers (Sinclair and Duthie, 1949, 1950 Ross, 1950; Jeffrey, 1952, 1953a, 1953b; Millardand Barber, 1956; McCrea, 1958) have shown toge the administration of saccharated oxide of iranpo (S.O.I.) intravenously produces a satisfactory in the haemoglobin level in a varying proportion.of cases. Using doses of 1 g., Jeffrey (1952) suggested that response occurs most frequently in patients with" co-existing iron deficiency as evidenced by a raised $\mathbb{D}$ total iron-binding capacity, low plasma iron, and low mean cell haemoglobin concentration. This view is supported by the results of McCrea (1958), which show that, of his eleven patients who had a "significant" response (a rise in haemoglobin leve or more than $2 \mathrm{~g}$. $/ 100 \mathrm{ml}$.), all but one had nos stainable iron in the marrow and in only two couldo no cause for simple iron-deficiency be found.

Sinclair and Duthie (1950) noticed a fall in theo erythrocyte sedimentation rate (E.S.R.) in many of their cases who responded to intravenous S.O.I을 This observation had led to the suggestion that clinical improvement after hospital treatment? unrelated to the use of S.O.I., may have led to an improvement in the anaemia. Our previous experio ence does not confirm this view, and it would seem 5 equally likely that the clinical improvement freN quently observed during treatment with S.O.I. mayo be attributable to some action other than a directs effect on haemopoiesis.

For these reasons it was considered importan to undertake a further assessment of the value of 
S.O.I. in rheumatoid arthritis. The object of the present paper is to report the results of a controlled therapeutic trial. In previous studies 1 to $2 \mathrm{~g}$. S.O.I. have been given and up to 60 per cent. of patients have shown some improvement. In view of the possibility that a higher proportion of cases might respond if larger doses were given, the treated group in the present study were given a total of 5 g. S.O.I. The initial iron content of the bone marrow, the findings in the peripheral blood, the clinical status of the patients throughout the period of observation, and, in some cases, the rate of clearance of S.O.I. during the period of its administration have been recorded.

\section{Material}

46 hospital patients were admitted to the trial. The diagnosis of rheumatoid arthritis had been established in each patient on clinical and radiological grounds, and all were undergoing the same basic regimen of treatment (rest, salicylates, splintage, and physiotherapy). Only patients in whom there was no known cause for anaemia other than rheumatoid arthritis were included. 26 cases were placed in the group to be treated and twenty in the control group by random allocation. The composition of the groups with regard to sex, age and duration of disease is shown in Table I.

TABLE I

COMPOSITION OF TREATED AND CONTROL GROUPS

\begin{tabular}{|c|c|c|c|c|c|}
\hline Group & $\cdots$ & $\cdots$ & $\cdots$ & Treated & Control \\
\hline Number of Patients .. & $\cdots$ & . & $\cdots$ & 26 & 20 \\
\hline Sex & & $\begin{array}{ll}\text { Male } & \ldots \\
\text { Female } & \ldots\end{array}$ &.. & $\begin{array}{l}10 \\
16\end{array}$ & $\begin{array}{r}7 \\
13\end{array}$ \\
\hline \multirow[t]{2}{*}{ Age Distribution (yrs) } & & $\begin{array}{l}20-39 \\
40-59 \\
60-79\end{array}$ & $\begin{array}{l}\cdots \\
\cdots\end{array}$ & $\begin{array}{r}2 \\
13 \\
11\end{array}$ & $\begin{array}{r}2 \\
12 \\
6\end{array}$ \\
\hline & & Mean & $\cdots$ & $56 \cdot 4$ & $53 \cdot 5$ \\
\hline \multirow[t]{2}{*}{ Duration of Disease (yrs) } & & $\begin{array}{l}\text { Under } 2 . \\
2-10 \\
\text { Over } 10\end{array}$ & $\begin{array}{c}\cdots \\
\cdots \\
\cdots\end{array}$ & $\begin{array}{r}4 \\
14 \\
8 \\
\end{array}$ & $\begin{array}{l}2 \\
9 \\
9\end{array}$ \\
\hline & & Mean & $\cdots$ & $7 \cdot 95$ & $9 \cdot 10$ \\
\hline
\end{tabular}

\section{Methods}

Each patient was observed in hospital for a period of approximately 2 weeks before being allocated to one of the two groups. During this time the activity of the disease and the functional capacity of each patient were assessed, the basic regimen of treatment was established, and the peripheral blood (Hb, R.B.C., P.C.V., E.S.R.) was examined on two or three occasions. In addition, the plasma iron concentration was estimated and bone marrow was obtained for a study of its iron content.

In the cases allotted to the treatment group, S.O.I. was administered intravenously in a dose of $200 \mathrm{mg}$. daily to a total of $5 \mathrm{~g}$. In the treated and the control groups, the peripheral blood was examined each week during the period in hospital (usually 6 to 8 weeks) and the plasma iron was measured at regular intervals. Thereafter all patients were reviewed in respect of changes in the activity of the disease, functional capacity, peripheral blood findings, and plasma iron levels, one month and 3 months after the course of S.O.I. in the treated group, and at similar intervals after discharge from hospital in the control group.

Disease Activity and Functional Capacity.-The criteria for grading functional capacity and disease activity were those used by Duthie, Brown, Knox, and Thompson (1957), and are reproduced in Tables II and III.

TABLE II

GRADES OF FUNCTIONAL CAPACITY

\begin{tabular}{|c|c|c|}
\hline Grade & Definition & Remarks \\
\hline 1 & $\begin{array}{l}\text { Fit for all normal } \\
\text { activities }\end{array}$ & $\begin{array}{l}\text { Full employment in usual work } \\
\text { Full house duties }\end{array}$ \\
\hline II & Moderate restriction & $\begin{array}{l}\text { Usual employment with modifica- } \\
\text { tions } \\
\text { Light or part-time work } \\
\text { All housework save the heaviest } \\
\text { No dependency on others }\end{array}$ \\
\hline III & Marked restriction & $\begin{array}{l}\text { Only very light work or light house- } \\
\text { work } \\
\text { Some degree of dependency on } \\
\text { others }\end{array}$ \\
\hline IV & $\begin{array}{l}\text { Confined to chair or } \\
\text { bed }\end{array}$ & $\begin{array}{l}\text { Not capable of any work } \\
\text { Completely dependent on others }\end{array}$ \\
\hline
\end{tabular}

TABLE III

GRADES OF DISEASE ACTIVITY

\begin{tabular}{|c|c|c|c|c|c|}
\hline Grade & $\begin{array}{l}\text { Degree of } \\
\text { Activity }\end{array}$ & $\begin{array}{c}\text { Erythrocyte } \\
\text { Sedimentation Rate } \\
\text { (mm./hr) }\end{array}$ & $\begin{array}{l}\text { Haemoglobin } \\
\text { (per cent.) }\end{array}$ & Joint Involvement & Systemic Disturbance \\
\hline 1 & Inactive & 20 or Under & 85 or Over & $\begin{array}{l}\text { No symptoms due to in- } \\
\text { flammation in the joints }\end{array}$ & None \\
\hline 2 & $\begin{array}{l}\text { Moderately } \\
\text { Active }\end{array}$ & $20-60$ & $65-85$ & $\begin{array}{l}\text { Signs of activity in several } \\
\text { joints }\end{array}$ & Moderate, weight steady \\
\hline 3 & Very Active & Over 60 & 65 or Under & $\begin{array}{l}\text { Signs of acute inflammation } \\
\text { in many joints }\end{array}$ & Marked, with loss of weight \\
\hline
\end{tabular}


Peripheral Blood Examination.-The methods for estimating Hb, R.B.C., P.C.V., E.S.R., and plasma iron concentration were the same as those described in earlier papers (Roy and others, 1955; Richmond and others, 1956). Haemoglobin values were recorded on the scale 100 per cent. $=14.3 \mathrm{~g} . / 100 \mathrm{ml}$.

Iron Content of Bone Marrow.-In 36 cases (nineteen in the treated group and seventeen controls) the iron content of the bone marrow was estimated by one of us (D.L.G.) using the technique described by Richmond and others (1956). In 26 subjects (fourteen in the treated group and twelve controls) the marrow iron was measured chemically (Kerr, 1957).

Rate of Clearance of S.O.I.-In eleven patients in the treated group, the rate of clearance from the blood of a single dose of $200 \mathrm{mg}$. S.O.I. was measured at the start of the course, after a total of $2 \mathrm{~g}$. had been given, and again at the end.

Comparison of Treated and Control Groups at Start of Trial.-The treated and control groups were similar in respect of age, sex, and duration of disease (Table I). The iron content of the bone marrow in each group was comparable (Table IV). At the start of the trial the differences between the grades of functional capacity and disease activity and the E.S.R. in the two groups were not significant (in each case $p>0 \cdot 1$ ). The initial mean haemoglobin level was significantly lower in the treated group than in the controls $(p<0.05)$. Full consideration has been given to the influence which this difference might have had on the results of the investigation. The relationship between the initial $\mathrm{Hb}$ level and the subsequent improvement in $\mathrm{Hb}$ was calculated in the control group. In estimating the increment in $\mathrm{Hb}$ which might have been expected in the treated group on the basis of this calculation, it was found that the improvement which actually occurred after the administration of S.O.I. far exceeded that which could have been explained by the relatively lower $\mathrm{Hb}$ level in this group at the start of the trial.

When the initial data from all 46 patients in the trial were considered, it was confirmed that the severity of the anaemia varied directly with the activity of the disease as measured by the E.S.R. $(p<0.05)$. There was a highly significant relationship between the $\mathrm{Hb}$ level and the M.C.H.C. $(p<0.001)$. As had been previously noted, no correlation existed between the $\mathrm{Hb}$, the plasma iron concentration, and the iron content of the bone marrow.

The clinical and laboratory data from all the patients studied in the trial are presented in the Appendix.

\section{Results}

\section{Changes following Administration of S.O.I.}

Hb, R.B.C., and M.C.H.C.-The mean haemoglobin level in the treated group showed an increase from an initial value of 73.1 to 91.9 per cent. 1 month after the last injection. The mean level was maintained at 3 months. All the cases in the treated group had improved at the one month assessment and after 3 months the $\mathrm{Hb}$ had fallen below the pre-treatment level in only two cases. In sixteen cases the $\mathrm{Hb}$ increased by more than 14 per cent. $(2 \mathrm{~g} . / 100 \mathrm{ml}$.), in eight cases by 7 to 14 per cent. $(1-2 \mathrm{~g} . / 100 \mathrm{ml}$.), and in only two by less than 7 per cent. An examination of results in individuals showed that sixteen patients had attained their maximum response by 1 month, and that the remaining ten patients reached the highese haemoglobin level between 1 and 3 months after the last injection of S.O.I.

In the control group the mean $\mathrm{Hb}$ level was initially $79 \cdot 1$ per cent., at 1 month 82.0 per cent., and at 3 months 83.9 per cent. In only two patients in this group did the increase in haemoglobin during the period of observation exceed 14 per cent.

The difference between the improvement in the treated and control groups was significant $(p<0.01)$. This is illustrated in the Figure (opposite).

When the mean values of the haematological indices in the treated and control groups are compared (Appendix), it appears that the better response of the treated group was not due to correction of the M.C.H.C., the change in the M.C.H.C. being small and of the same order in both groups.

TABLE IV

IRON CONTENT OF BONE MARROW IN TREATED AND CONTROL GROUPS

\begin{tabular}{|c|c|c|c|c|c|c|}
\hline \multirow{3}{*}{\multicolumn{2}{|c|}{ Method of Assessment }} & \multicolumn{5}{|c|}{ Iron Content of Bone Marrow } \\
\hline & & \multicolumn{3}{|c|}{ Prussian Blue } & \multicolumn{2}{|c|}{ Chemical } \\
\hline & & Total & Nil and Trace & + and ++ & Total & $\begin{array}{c}\text { Mean Value } \\
\text { (mg./100 g. Protein) }\end{array}$ \\
\hline \multirow{2}{*}{ Group } & Treated & 19 & 11 & 8 & 14 & $55 \pm 28$ \\
\hline & Control & 17 & 10 & 7 & 12 & $43 \pm 17$ \\
\hline
\end{tabular}




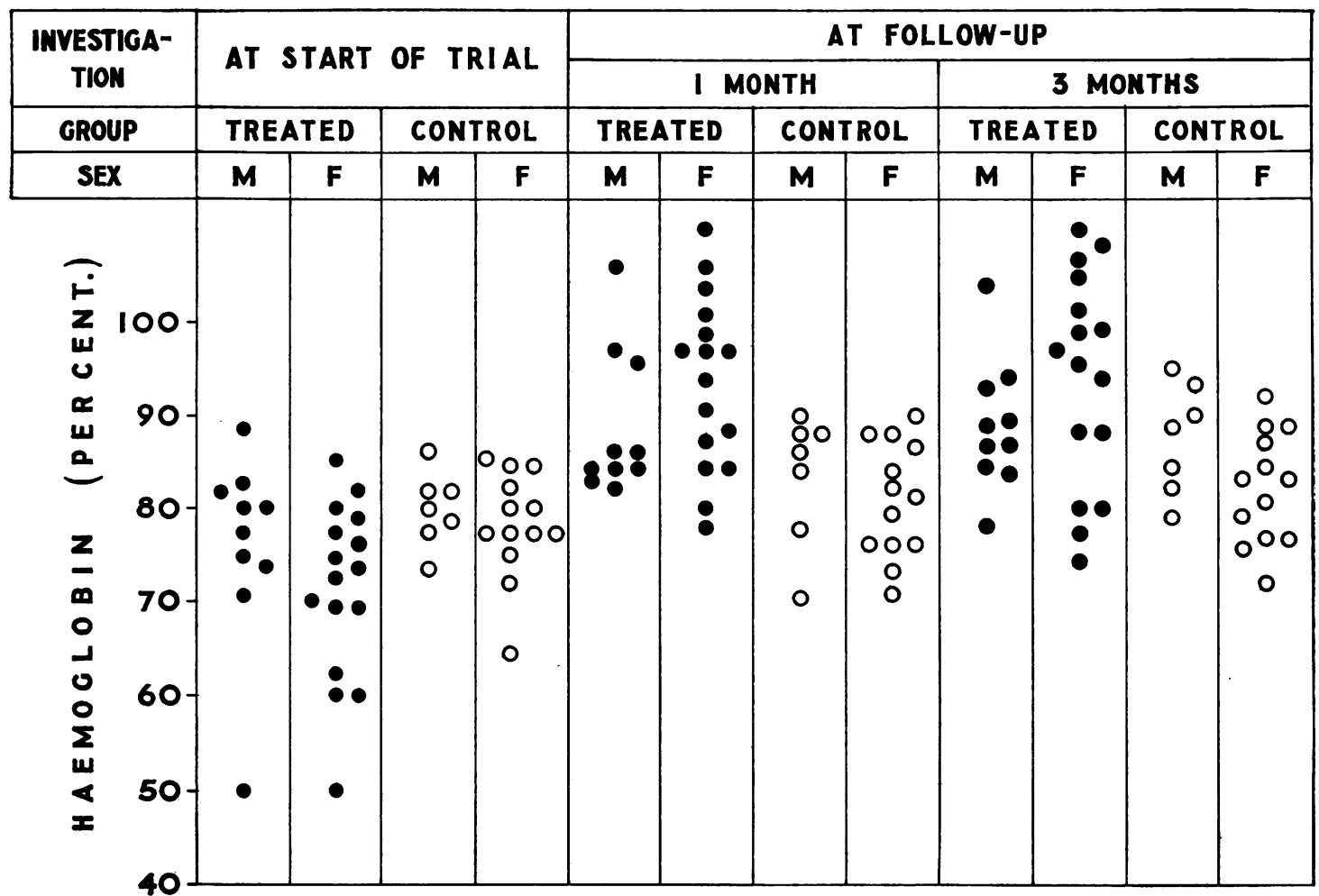

Figure.-Improvement in haemoglobin levels in treatment and control groups, by sex.

The improvement observed in the patients receiving S.O.I. seems to be attributable mainly to a rise in the red cell count. In the treated group the mean R.B.C. count was higher than the initial value by 13.5 per cent. after 1 month and by 12.5 per cent. after 3 months. In the controls the comparable figures were 1 per cent. in each case.

The data given in the Appendix show that, in eight patients in the treated group, the initial haemoglobin level was 70 per cent. or lower. As only one of the controls had such a low haemoglobin level, it was decided to examine the character and response of the anaemia in these patients in further detail. The results are presented in Table $V$, which shows that the patients presenting with a haemoglobin level of 70 per cent. or less (Group I) differed from the remainder of the treated group (Group II) in several respects.

The mean initial R.B.C., M.C.H.C., and M.C.V. in the patients in Group I were consistently lower than those recorded in the remainder of the treated group. Analysis of the response to S.O.I. reveals

RELATIONSHIP OF HAEMATOLOGICAL INDICES AND PLASMA IRON TO INITIAL HAEMOGLOBIN LEVEL IN TREATED GROUP

\begin{tabular}{|c|c|c|c|c|c|c|}
\hline \multirow[t]{2}{*}{ Group } & \multicolumn{3}{|c|}{$\begin{array}{c}I \\
\text { Initial } \mathrm{Hb} \\
\text { (8 patients) }\end{array}$} & \multicolumn{3}{|c|}{$\underset{\text { Initial Hb } 71 \text { per cent. or More }}{\text { (18 patients) }}$} \\
\hline & Before Treatment & 1/12 Follow-up & 3/12 Follow-up & Before Treatment & 1/12 Follow-up & 3/12 Follow-up \\
\hline Mean R.B.C. Count (m/cu. mm.) & $4 \cdot 12$ & $4 \cdot 87$ & $4 \cdot 66$ & $4 \cdot 49$ & $5 \cdot 05$ & $5 \cdot 02$ \\
\hline Mean M.C.H.C. (per cent.) & $28 \cdot 3$ & $31 \cdot 6$ & $31 \cdot 5$ & $30 \cdot 9$ & $31 \cdot 3$ & $31 \cdot 8$ \\
\hline Mean M.C.V. $(c \mu)$ & $77 \cdot 3$ & $88 \cdot 4$ & $90 \cdot 3$ & $85 \cdot 6$ & $86 \cdot 2$ & $85 \cdot 9$ \\
\hline Mean Plasma Iron ( $\mu \mathrm{g} . / 100 \mathrm{ml})$. & 57 & 73 & 74 & 75 & 101 & 91 \\
\hline
\end{tabular}


a further difference between Groups I and II. Thus, in the more anaemic individuals, the mean M.C.H.C. had risen by 11.3 per cent. of the initial value at 1 month, as compared with a rise of $1 \cdot 3$ per cent. in the remainder of the patients who were given S.O.I. The mean rise in R.B.C. in all the treated patients has already been commented upon, but it is apparent from Table $\mathrm{V}$ that this rise was slightly greater in Group I.

The mean M.C.V., which was below the normal range in Group I, was corrected by the 1 month follow-up.

Beyond the 1 month follow-up no material difference in the response of the two groups to S.O.I. was detected.

E.S.R.-In the patients treated with S.O.I., a marked fall in the E.S.R. occurred. At the start of the trial the mean level was $60 \mathrm{~mm}$./ hr, and 1 month after the end of the course of S.O.I. it was $29 \mathrm{~mm}$./hr. By 3 months, however, the mean had risen to $37 \mathrm{~mm}$./hr. Only one patient had an E.S.R. of less than $20 \mathrm{~mm}$./ $/ \mathrm{hr}$ initially, but the rate had fallen to this level in eleven cases at the 1 month follow-up. In contrast, the mean E.S.R. in the control group showed little change during the period of observation and the difference between the treated and control groups was significant $(p<0.01)$.

Plasma Iron Level.-Whereas the mean plasma iron level in the control group showed a slight fall during the time of the trial, that in the treated group improved from $70 \mu \mathrm{g} . / 100 \mathrm{ml}$. initially to $93 \mu \mathrm{g}$./ $100 \mathrm{ml}$. at one month, falling to $86 \mu \mathrm{g} . / 100 \mathrm{ml}$. at 3 months. Only four of the 26 patients in the treated group failed to show a higher level of plasma iron in the 3 months after receiving S.O.I. On the other hand, only four of the controls showed any improvement.

Comparison of the initial mean plasma iron levels in the eight more anaemic patients with the eighteen other patients in the treated group (Table V) reveals a lower level in the former, seven of whom were females. In six out of seven of these patients in whom marrow iron was estimated, iron was absent or present only in trace amounts.

Rate of Clearance of S.O.I.-In eleven patients in whom serial measurements of the clearance of $200 \mathrm{mg}$. S.O.I. were made, no change in the speed of clearance consequent on the administration of increasing amounts of iron was demonstrated. The mean rates of clearance from the plasma of a single injection of S.O.I. at the start of treatment, after 2 g. S.O.I. had been given, and at the end of the course, are shown in Table VI.
TABLE VI

RATE OF CLEARANCE OF S.O.I. AFTER ADMINISTRATION OF INCREASING AMOUNTS IN ELEVEN PATIENTS

\begin{tabular}{c|c|c|c|c}
\hline $\begin{array}{c}\text { Amount of S.O.I. } \\
\text { given before } \\
\text { Estimation of }\end{array}$ & \multicolumn{2}{|c|}{ Mean Plasma } & $\begin{array}{c}\text { Iron Levels during Clearance } \\
(\mu \mathrm{g} . / 100 \mathrm{ml})\end{array}$ & \\
\cline { 2 - 4 } Clearance (mg.) & Before & $12 \mathrm{hrs}$ & $18 \mathrm{hrs}$ & $24 \mathrm{hrs}$ \\
\hline 200 & 88 & 265 & 179 & 119 \\
2,200 & 96 & 180 & 129 & 106 \\
5,000 & 139 & 194 & 155 & 142 \\
\hline
\end{tabular}

Functional Capacity.-During the trial, improvement occurred in the grade of functional capacity in fifteen patients in the treated group, nine remained in the same grade, and two deteriorated. In the control group fourteen remained in the same grade throughout the trial and only six were placed in a higher grade at the 1 month or 3 month follow-up. The improvement which occurred in the treated group between the start of the trial and the 3 month follow-up was significant $(p<0.02)$, whereas the change in the control group was not.

Disease Activity.-In fourteen patients in the treated group the disease became less active during the trial and in twelve there was no change. The improvement between the initial assessment and then 3 month follow-up in this group was significanto $(p<0.01)$. In the control group activity of the disease decreased in only three patients at the month or 3 month follow-up, and in seventeen there was no change.

\section{Factors Influencing Response to S.O.I.}

Age and Sex.-The improvement in $\mathrm{Hb}$ levels tended to be greater in the older subjects than in the younger, but this was only a trend and did not reach levels of significance.

It was found that a greater rise in $\mathrm{Hb}$ level occurred in female patients in the treated group than in males (Table VII).

TABLE VII

IMPROVEMENT IN HAEMOGLOBIN LEVEL IN TREATED AND CONTROL GROUPS BY SEX

\begin{tabular}{|c|c|c|c|c|c|}
\hline \multirow{2}{*}{$\frac{\text { Sex } \cdots}{\text { Group } \cdots}$} & \multirow{2}{*}{$\cdots$} & \multicolumn{2}{|c|}{ Male } & \multicolumn{2}{|c|}{ Female } \\
\hline & & Treated & Control & Treated & Control \\
\hline \multirow{2}{*}{$\begin{array}{c}\text { Mean } \\
\text { Haemoglobin } \\
\text { Increment } \\
\text { (per cent.) }\end{array}$} & $\begin{array}{l}1 \text { Month } \\
\text { Follow-up }\end{array}$ & $13 \cdot 0$ & $3 \cdot 3$ & $23 \cdot 2$ & $1 \cdot 3$ \\
\hline & $\begin{array}{l}3 \text { Month } \\
\text { Follow-up }\end{array}$ & $12 \cdot 7$ & $6 \cdot 7$ & $21 \cdot 2$ & $3 \cdot 2$ \\
\hline
\end{tabular}

The mean $\mathrm{Hb}$ level in males at the start of the trial was 75.5 per cent. and in females it was 71.4 
per cent. Only in respect of the plasma iron concentration (males $85.1 \mu \mathrm{g} . / 100 \mathrm{ml}$., females $59.9 u \mathrm{~g} . / 100 \mathrm{ml}$.) was there an appreciable difference between the initial findings in the two sexes.

Hb Level, E.S.R., and Plasma Iron Concentration before Treatment.-The increase in haemoglobin which occurred after the administration of S.O.I. was closely related to the initial degree of anaemia $(p<0 \cdot 01)$. Despite the fact that the $\mathrm{Hb}$ level was found to correlate with the activity of the disease, the initial E.S.R. showed no relationship to the subsequent improvement.

The degree of hypoferraemia at the start of the trial was not related to the response to S.O.I. Hence the better response of the females in the treated group compared with the males could not be attributed to their lower initial plasma iron concentration.

Iron Content of Bone Marrow.-The iron content of the bone marrow as estimated by the Prussian blue and chemical methods showed no relationship to the improvement in the $\mathrm{Hb}$ level or to the fall in E.S.R. which occurred after the administration of S.O.I. The lack of correlation between the improvement in haemoglobin level and the iron content of the marrow is shown in Table VIII. The nineteen patients tested by the Prussian blue method were divided into two groups depending on whether they were found to have reduced amounts of stainable iron in the marrow (nil or a trace) or easily detected amounts $(+$ or ++$)$. In those with a reduced marrow iron content, the $\mathrm{Hb}$ improved from 73 per cent. initially to 92 per cent. at 1 month and 93 per cent. at 3 months. Those with normal or excessive amounts of stainable iron improved from 74 per cent. initially to 90 per cent. at 1 month and 91 per cent. at 3 months. The result was similar

\section{TABLE VIII}

RELATIONSHIP BETWEEN IMPROVEMENT IN HAEMOGLOBIN LEVEL AND INITIAL IRON CONTENT OF BONE MARROW IN TREATED GROUP

\begin{tabular}{|c|c|c|c|c|c|}
\hline \multirow{3}{*}{\multicolumn{2}{|c|}{\begin{tabular}{c}
\multicolumn{1}{c}{$\begin{array}{c}\text { Time } \\
\text { of } \\
\text { Assessment }\end{array}$}
\end{tabular}}} & \multicolumn{4}{|c|}{ Iron Content of Bone Marrow } \\
\hline & & \multicolumn{2}{|c|}{$\begin{array}{l}\text { Prussian Blue Method } \\
\text { (19 cases) }\end{array}$} & \multicolumn{2}{|c|}{$\begin{array}{l}\text { Chemical Method } \\
\text { (14 cases) }\end{array}$} \\
\hline & & $\begin{array}{l}\text { Nil and } \\
\text { Trace }\end{array}$ & $\begin{array}{c}+ \text { and } \\
++\end{array}$ & 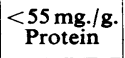 & $\begin{array}{l}>55 \mathrm{mg} . / \mathrm{g} \\
\text { Protein }\end{array}$ \\
\hline \multirow{3}{*}{$\begin{array}{c}\text { Hb } \\
\text { (per } \\
\text { cent.) }\end{array}$} & $\begin{array}{l}\text { Start of } \\
\text { Trial }\end{array}$ & 73 & 74 & 77 & 77 \\
\hline & $\begin{array}{l}1 \text { Month } \\
\text { Follow-up }\end{array}$ & 92 & 90 & 93 & 95 \\
\hline & $\begin{array}{l}3 \text { Month } \\
\text { Follow-up }\end{array}$ & 93 & 91 & 92 & 96 \\
\hline
\end{tabular}

when the fourteen patients, tested by the chemical method, were divided into two groups depending on whether the amount of iron was less or more than the mean level of $55 \mathrm{mg}$. $/ 100 \mathrm{~g}$. protein.

\section{Side-Effects of the Administration of S.O.I.}

Despite the high doses of S.O.I. used in the trial, side-effects were notable by their absence. Only one patient complained of unpleasant symptoms in the form of flushing and back-ache after the first three to four injections.

\section{Discussion}

The results of this trial leave no doubt that the intravenous administration of saccharated oxide of iron leads both to improvement in anaemia and to diminution of disease activity in patients suffering from rheumatoid arthritis. A rise in the haemoglobin level of more than 14 per cent. $(2 \mathrm{~g}$. per $100 \mathrm{ml}$. ), a figure adopted by Coleman, Stevens, and Finch (1955), and McCrea (1958) as constituting a significant response, occurred in sixteen of 26 patients during the period of observation. The mean increase in haemoglobin in the treated group exceeded 18 per cent. $(2.7 \mathrm{~g}$. per $100 \mathrm{ml}$.). By contrast, in the control group, the haemoglobin level improved by more than 14 per cent. in only two patients, the mean rise for the group being less than 5 per cent. $(0.7 \mathrm{~g}$. per $100 \mathrm{ml}$.).

The response to the administration of iron in simple iron deficiency anaemia is characterized by a proportionately greater rise in the M.C.H.C. than in the red cell count. In the majority of the treated group in this study only a slight increase in the M.C.H.C. took place, no greater than was observed in the controls. Only in those patients whose haemoglobin was below 70 per cent. before the administration of iron was a significant rise in M.C.H.C. and M.C.V. noted after one month, and their subsequent progress did not differ from the remainder of the treated group. It would appear that, in these eight patients of whom seven were females, a mild degree of iron deficiency was present, although no obvious cause was found.

Consideration of results in the treated group as a whole reveal other features which differentiate the response to S.O.I. in the anaemia of rheumatoid arthritis from that in simple iron deficiency. First, the increase in haemoglobin shows no relationship to the iron content of the bone marrow as estimated before the start of treatment. It has been reported by previous authors (Rath and Finch, 1948; Hutchison, 1953) that only those patients in whom 
iron cannot be demonstrated in the marrow by the Prussian blue technique will respond to the administration of iron. Although stainable iron was absent or present in reduced amounts in eleven of nineteen patients in the treated group, their response did not differ significantly from that of the remaining eight patients in whom it was demonstrated in normal or increased quantities.

Secondly, in iron deficiency anaemia there is maximal utilization of iron given in the form of S.O.I. by the intravenous route. The haemoglobin level rises by approximately 1 per cent. for each $25 \mathrm{mg}$. iron administered. No such dose-response could be demonstrated in this investigation. This may be related to the fact that, although absorption from the gut is normal in rheumatoid arthritis, the administration of iron by mouth is usually ineffective. These observations suggest that the dose of iron required to achieve a satisfactory response is much greater than the amount which would be required to correct anaemia due to simple iron deficiency and is probably very much in excess of the amount which can normally be absorbed from the alimentary tract.

Thirdly, improvement in the anaemia in the treated group was largely accounted for by the rise in the red cell count. This had increased by 13.5 per cent. of the initial count at the one month assessment and was well maintained after 3 months. Since there is no evidence that the administration of S.O.I. prolongs the life-span of red cells, the main effect on the blood picture of S.O.I. in the doses given must have been to increase, directly or indirectly, the capacity of the marrow to produce red cells.

In the anaemia of infection, which has been investigated in detail by Cartwright and Wintrobe (1955), hypoferraemia is a constant feature. It has been suggested that, in the presence of inflammation, iron is removed from the circulation by cells of the reticulo-endothelial system. The purpose of this uptake is unknown, but the possibility that saturation of the system with iron might be of benefit prompted the large doses used in this trial. Evidence for such saturation was sought by serial estimations of plasma iron and by the measurement of iron clearance at intervals throughout the course. Although a moderate rise in plasma iron took place, this bore no direct relationship to the rise in haemoglobin. In eleven patients in whom clearances were measured at intervals, the rate remained abnormally rapid. It would appear that, although the administration of $5 \mathrm{~g}$. S.O.I. was followed by improvement in the blood picture in every case, even larger amounts may be required to restore plasma iron to normal levels and to saturate the cells of the reticulo-endothelial system. Whether the administration of such larger quantities would achieve more satisfactory results without toxic effects cannot be predicted at present.

Perhaps the most remarkable change following the course of treatment was the striking fall in the mean E.S.R., accompanied by a significant improvement in functional capacity. That these changes cannot be attributed to the basic regimen of treatment used in all patients is authenticated by the significant difference between the treated group and controls. It would now appear justifiable to state with some confidence that in the majority of cases the beneficial effects of S.O.I. are due to a reduction in disease activity with concomitant improvement in the anaemia and not to the correction of iron deficiency at the level of the bone marrow.

Saccharated oxide of iron is rapidly removed from circulation by the phagocytic cells of the reticuloendothelial system (Benacerraf, Biozzi, Halpern, and Stiffel, 1957). The same authors have shown experimentally that repeated injections of S.O.I. and other colloids have a powerful stimulating effect on the reticulo-endothelial system in animals. They state that the mechanism of this action is unknown, but the evidence suggests that it is due t $\delta$ an increase in the number of phagocytic cells. The have also shown that the reticulo-endothelia system resists remarkably all attempts to blockade its phagocytic activity by the injection of colloidal particles (Biozzi, Halpern, Benacerraf, and Stiffel, 1957). This observation is in keeping with the failure of $5 \mathrm{~g}$. S.O.I. to alter the abnormally rapid clearance of a single dose of $200 \mathrm{mg}$. in these patients.

What bearing these facts may have on the therapeutic effect of large doses of S.O.I. in rheumatoid arthritis is quite unknown at present. The possibility exists that the observed effects of S.O.I. may not depend on its iron content and that similar results might follow the use of other colloids.

The authors do not recommend the routine use of such large doses of S.O.I. in the treatment of rheumatoid arthritis, but the results of this controlled trial would certainly indicate the need for a more detailed investigation of the metabolism of this compound, with particular reference to its possible $\%$ effects on the function of the reticulo-endothelial $N$ system.

\section{Summary}

(1) The effects of the intravenous administration of $5 \mathrm{~g}$. saccharated oxide of iron were studied in a $\stackrel{?}{\rightarrow}$ group of 26 patients suffering from rheumatoid $T$

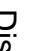

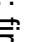
.

\section{.}


arthritis. Their progress was compared with that of twenty patients who received the same basic regimen of treatment, but to whom no iron was given.

(2) The treated group showed a significantly greater improvement in the anaemia than the control group.

(3) The rise in the haemoglobin level in the treated group was associated with a fall in the mean level of the erythrocyte sedimentation rate. Functional capacity improved and disease activity diminished simultaneously.

(4) The rise in the haemoglobin level resulting from the administration of saccharated oxide of iron was not related to the initial iron content of the marrow, the degree of anaemia, the mean corpuscular haemoglobin concentration, the plasma iron level, or the activity of the disease.

(5) Improvement in anaemia in the treated patients was due mainly to a rise in the red cell count and not to correction of hypochromia.

(6) The significance of these findings is discussed.

During the period when this work was done, the Rheumatic Unit was in receipt of grants from the Nuffield Foundation, the Medical Research Council, and Boots Pure Drug Company Limited.

We wish to express our thanks to Dr. J. L. Potter for assistance with the statistical aspect of the investigation and to Miss Dorothy Anderson, haematological technician, for her accurate and painstaking work throughout the investigation.

\section{REFERENCES}

Alexander, W. R. M., Richmond, J., Roy, L. M. H., and Duthie, J. J. R. (1956). Ann. rheum. Dis., 15, 12.

Benacerraf, B., Biozzi, G., Halpern, B. N., and Stiffel, C. (1957). ed. B. Benacerraf and J. F. Delafresnaye, p. 52. Blackwell Scientific Publications, Oxford.

Biozzi, G., Halpern, B. N., Benacerraf, B., and Stiffel, C. (1957). Ibid., p. 204.

Cartwright, G. E., and Wintrobe, M. M. (1955). In "Modern Trends in Blood Diseases", ed. J. F. Wilkinson, p. 183. Butterworth, London.

Coleman, D. H., Stevens, A. R., Jr., and Finch, C. A. (1955). Blood,

Duthie, J. J. R., Brown, P. E., Knox, J. D. E., and Thompson, M., (1957). Ann. rheum. Dis., 16, 411.

Hutchison, H. E. (1953). Blood, 8, 236.

Jeffrey, M. R. (1952). Ann. rheum. Dis., 11, 162.

(1953a). Blood, 8, 502.

(1953b). Brit. med. J., $2,912$.

Freundlich, H. F., Jackson, E. B., and Watson, D. (1955). Clin. Sci., 14, 395.,

Kerr, L. M. H. (1957). Biochem. J., 67, 627.

McCrea, P. C. (1958). Ann. rheum. Dis., 17, 89.

Millard, J. B., and Barber, H. S. (1956). Ibid., 15, 51.

Rath, C. E., and Finch, C. A. (1948). J. Lab. clin. Med., 33, 81.

Richmond, J., Gardner, D. L., Roy, L. M. H., and Duthie, J. J. R. (1956). Ann. rheum. Dis., 15, 217.
Ross, D. N. (1950). Ibid., 9, 358. Roy, L. M. H., Alexander, W. R. M., and Duthie, J. J. R. (1955).

Sinclair, R. J. G., and Duthie, J. J. R. (1949). Lancet, 2, 646.

(1950). Brit. med. J., 2, 1257.

Nature de l'anémie dans l'arthrite rhumatismale

IV. Effets de l'administration intraveineuse d'oxyde saccharé de fer

RÉSUMÉ

(1) Les effets de l'administration intraveineuse de $5 \mathrm{~g}$. d'oxyde saccharé de fer furent étudiés chez un groupe de 26 malades atteints d'arthrite rhumatismale. Leur progrès fut comparé à celui de 20 malades soumis à un régime de traitement similaire, mais sans la thérapie au fer.

(2) Le groupe traité accusa une amélioration de l'anémie appréciablement plus accentuée que le groupe témoin.

(3) L'augmentation du taux d'hémoglobine chez le groupe traité fut accompagnée d'une chute de la vitesse moyenne de la sédimentation érythrocytaire. La capacité fonctionnelle s'améliora et l'activité morbide diminua en même temps.

(4) L'augmentation du taux d'hémoglobine due à l'administration d'oxyde saccharé de fer ne fut pas en relation avec le taux initial de fer dans la moelle, la sévérité de l'anémie, la concentration corpusculaire d'hémoglobine, le taux plasmatique de fer ni l'activité morbide.

(5) L'amélioration de l'anémie des malades traités était due surtout au nombre augmenté d'érythrocytes et non pas à l'hypochromie corrigée.

(6) On discute la portée de ces résultats.

La naturaleza de la anemia en la artritis reumatoide. IV. Efectos de la administración endovenosa de óxido sacarado de hierro

\section{Sumario}

(1) Se estudiaron los efectos de la administración endovenosa de $5 \mathrm{~g}$. de óxido sacarado de hierro en un grupo de 26 enfermos con artritis reumatoide. Su progreso fué comparado al de 20 enfermos sometidos a un régimen básico similar, pero sin tratamiento férrico.

(2) El grupo tratado acusó una mejoría de la anemia significativamente mayor que el grupo testigo.

(3) El aumento de la tasa de hemoglobina en el grupo tratado se vió asociado a una caida del promedio de la velocidad de eritrosedimentación. La capacidad funcional mejoró y la actividad morbosa disminuyó al mismo tiempo.

(4) El aumento de la cifra de hemoglobina debido a la administración de óxido sacarado de hierro no se relacionaba con la tasa inicial del hierro medular, la severidad de la enfermedad, la concentración corpuscular de hemoglobina, la tasa plasmática de hierro ni la actividad morbosa.

(5) La mejoría de la anemia de los enfermos tratados se debió ante todo al aumento de la cifra eritrocitaria y no a la corrección de la hipocromia.

(6) Se discute el alcance de estos resultados. 
PRINCIPAL CLINICAL AND LABORATO

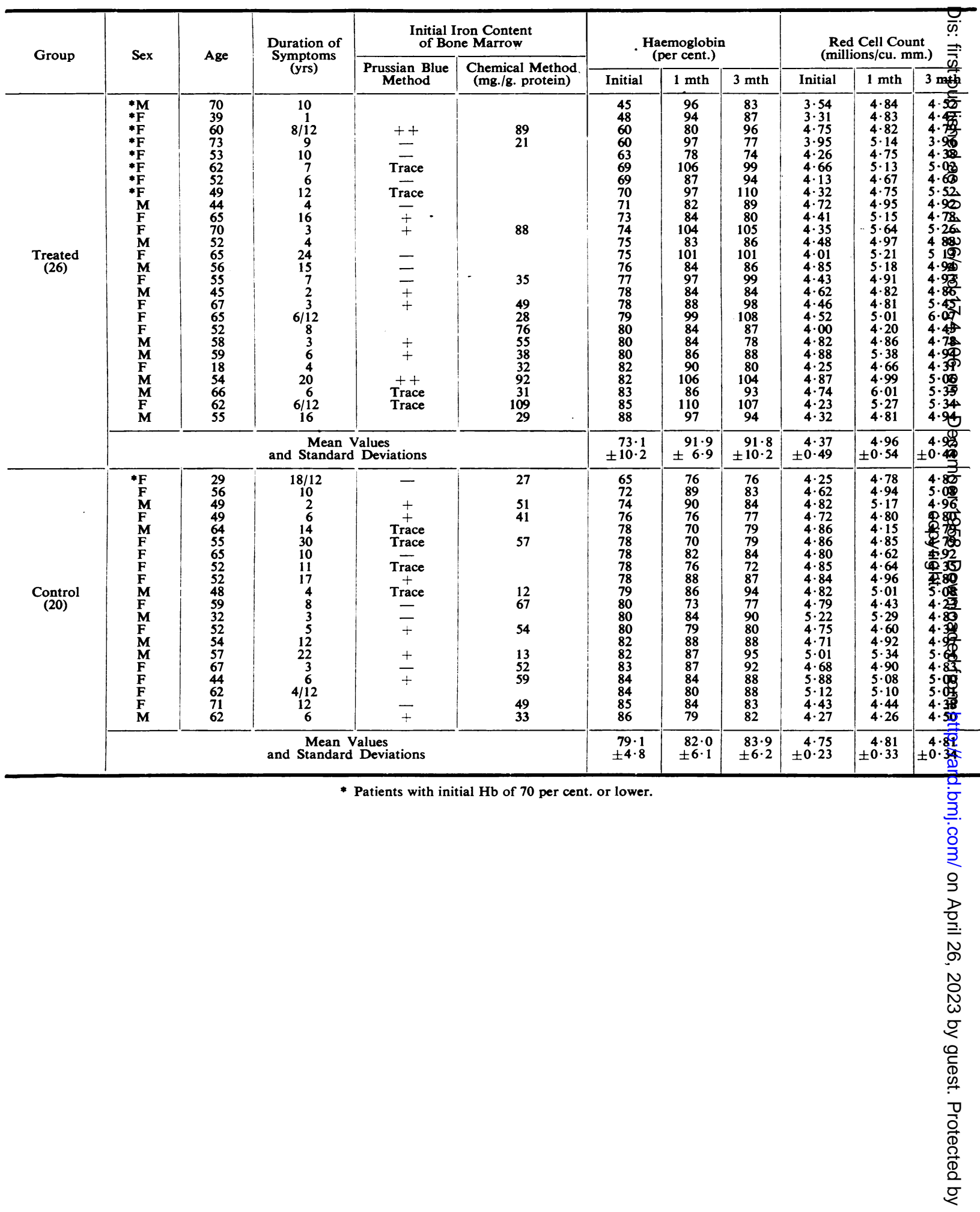


ATA OF PATIENTS STUDIED IN THE TRIAL

\begin{tabular}{|c|c|c|c|c|c|c|c|c|c|c|c|c|c|c|}
\hline \multicolumn{3}{|c|}{$\begin{array}{l}\text { Mean Corpuscular } \\
\text { Haemoglobin Concentration } \\
\text { (per cent.) }\end{array}$} & \multicolumn{3}{|c|}{$\begin{array}{l}\text { Plasma Iron } \\
(\mu \mathrm{g} . / 100 \mathrm{ml} .)\end{array}$} & \multicolumn{3}{|c|}{$\begin{array}{c}\text { Erythrocyte } \\
\text { Sedimentation Rate } \\
(\mathbf{m m} . / \mathrm{hr})\end{array}$} & \multicolumn{3}{|c|}{$\begin{array}{c}\text { Grade of } \\
\text { Functional Capacity }\end{array}$} & \multicolumn{3}{|c|}{$\begin{array}{c}\text { Grade of } \\
\text { Disease Activity }\end{array}$} \\
\hline Initial & $1 \mathrm{mth}$ & $3 \mathrm{mth}$ & Initial & $1 \mathrm{mth}$ & $3 \mathrm{mth}$ & Initial & $1 \mathrm{mth}$ & $3 \mathrm{mth}$ & Initial & $1 \mathrm{mth}$ & $3 \mathrm{mth}$ & Initial & $1 \mathrm{mth}$ & $3 \mathrm{mth}$ \\
\hline $\begin{array}{l}26 \cdot 4 \\
27 \cdot 3 \\
24 \cdot 0 \\
29 \cdot 7 \\
28 \cdot 2 \\
29 \cdot 8 \\
30 \cdot 0 \\
31 \cdot 2 \\
28 \cdot 2 \\
27 \cdot 8 \\
31 \cdot 2 \\
29 \cdot 2 \\
31 \cdot 8 \\
28 \cdot 6 \\
30 \cdot 8 \\
28 \cdot 4 \\
32 \cdot 9 \\
32.6 \\
30 \cdot 5 \\
32 \cdot 3 \\
29 \cdot 0 \\
33.9 \\
27.4 \\
31 \cdot 8 \\
34 \cdot 1 \\
32 \cdot 0\end{array}$ & $\begin{array}{l}31 \cdot 6 \\
30 \cdot 2 \\
30 \cdot 5 \\
31 \cdot 2 \\
29 \cdot 4 \\
34 \cdot 1 \\
31 \cdot 4 \\
34 \cdot 3 \\
29 \cdot 3 \\
29 \cdot 8 \\
32 \cdot 1 \\
30 \cdot 2 \\
31 \cdot 2 \\
28 \cdot 4 \\
31 \cdot 3 \\
29 \cdot 8 \\
34 \cdot 5 \\
32 \cdot 2 \\
31 \cdot 3 \\
30 \cdot 5 \\
28 \cdot 8 \\
34 \cdot 1 \\
32 \cdot 5 \\
30 \cdot 1 \\
35 \cdot 6 \\
32 \cdot 0\end{array}$ & $\begin{array}{l}31 \cdot 8 \\
30.7 \\
31 \cdot 6 \\
31 \cdot 6 \\
31 \cdot 2 \\
33.5 \\
30.9 \\
30.8 \\
31 \cdot 4 \\
29 \cdot 8 \\
33.0 \\
31 \cdot 8 \\
35 \cdot 7 \\
29.5 \\
32.6 \\
30.5 \\
30.9 \\
31.4 \\
32.2 \\
28.0 \\
31.2 \\
34.0 \\
33 \cdot 5 \\
31.6 \\
35.5 \\
29.2\end{array}$ & $\begin{array}{r}53 \\
28 \\
68 \\
44 \\
35 \\
74 \\
63 \\
95 \\
67 \\
120 \\
52 \\
70 \\
42 \\
123 \\
51 \\
125 \\
31 \\
24 \\
76 \\
68 \\
76 \\
86 \\
130 \\
87 \\
70 \\
54\end{array}$ & $\begin{array}{r}53 \\
50 \\
80 \\
44 \\
131 \\
79 \\
69 \\
\\
81 \\
158 \\
77 \\
123 \\
89 \\
132 \\
133 \\
123 \\
59 \\
28 \\
51 \\
69 \\
169 \\
170 \\
104 \\
115 \\
113 \\
60\end{array}$ & $\begin{array}{r}58 \\
80 \\
94 \\
54 \\
66 \\
63 \\
74 \\
104 \\
58 \\
94 \\
85 \\
75 \\
98 \\
99 \\
79 \\
118 \\
83 \\
109 \\
48 \\
127 \\
118 \\
100 \\
114 \\
82 \\
66\end{array}$ & $\begin{array}{r}118 \\
72 \\
60 \\
65 \\
85 \\
30 \\
36 \\
58 \\
108 \\
20 \\
72 \\
95 \\
44 \\
42 \\
49 \\
86 \\
70 \\
60 \\
88 \\
76 \\
26 \\
60 \\
9 \\
28 \\
41 \\
64\end{array}$ & $\begin{array}{r}44 \\
25 \\
29 \\
20 \\
82 \\
22 \\
19 \\
8 \\
19 \\
8 \\
17 \\
8 \\
19 \\
21 \\
39 \\
50 \\
44 \\
14 \\
72 \\
37 \\
12 \\
46 \\
7 \\
19 \\
40 \\
42\end{array}$ & $\begin{array}{r}66 \\
43 \\
39 \\
67 \\
43 \\
23 \\
16 \\
3 \\
38 \\
9 \\
34 \\
26 \\
18 \\
13 \\
62 \\
82 \\
29 \\
8 \\
88 \\
60 \\
8 \\
57 \\
29 \\
13 \\
42 \\
47\end{array}$ & $\begin{array}{r}\text { IV } \\
\text { II } \\
\text { II } \\
\text { IV } \\
\text { II } \\
\text { II } \\
\text { III } \\
\text { IV } \\
\text { III } \\
\text { III } \\
\text { III } \\
\text { III } \\
\text { III } \\
\text { III } \\
\text { III } \\
\text { II } \\
\text { III } \\
\text { III } \\
\text { IV } \\
\text { II } \\
\text { III } \\
\text { III } \\
\text { II } \\
\text { II } \\
\text { III } \\
\text { IV }\end{array}$ & $\begin{array}{r}\text { II } \\
\text { I } \\
\text { II } \\
\text { II } \\
\text { II } \\
\text { II } \\
\text { III } \\
\text { III } \\
\text { II } \\
\text { III } \\
\text { III } \\
\text { II } \\
\text { II } \\
\text { II } \\
\text { III } \\
\text { I } \\
\text { II } \\
\text { III } \\
\text { III } \\
\text { II } \\
\text { II } \\
\text { III } \\
\text { I } \\
\text { II } \\
\text { II } \\
\text { III }\end{array}$ & $\begin{array}{r}\text { II } \\
\text { I } \\
\text { II } \\
\text { II } \\
\text { II } \\
\text { II } \\
\text { III } \\
\text { II } \\
\text { II } \\
\text { IV } \\
\text { III } \\
\text { II } \\
\text { III } \\
\text { I } \\
\text { III } \\
\text { I } \\
\text { II } \\
\text { IV } \\
\text { III } \\
\text { II } \\
\text { II } \\
\text { II } \\
\text { I } \\
\text { II } \\
\text { II } \\
\text { III }\end{array}$ & $\begin{array}{l}3 \\
3 \\
2 \\
3 \\
3 \\
2 \\
2 \\
2 \\
3 \\
2 \\
2 \\
3 \\
2 \\
3 \\
2 \\
3 \\
2 \\
3 \\
3 \\
2 \\
2 \\
2 \\
2 \\
2 \\
2 \\
3\end{array}$ & $\begin{array}{l}2 \\
2 \\
2 \\
1 \\
2 \\
2 \\
2 \\
2 \\
2 \\
2 \\
2 \\
1 \\
2 \\
2 \\
2 \\
2 \\
2 \\
3 \\
3 \\
2 \\
1 \\
2 \\
1 \\
2 \\
2 \\
2\end{array}$ & $\begin{array}{l}2 \\
2 \\
2 \\
2 \\
2 \\
2 \\
2 \\
2 \\
2 \\
1 \\
2 \\
2 \\
2 \\
1 \\
2 \\
2 \\
2 \\
2 \\
2 \\
2 \\
1 \\
2 \\
2 \\
2 \\
2 \\
2\end{array}$ \\
\hline $\begin{array}{r}30.4 \\
\pm 0.6\end{array}$ & $\begin{array}{r}31 \cdot 4 \\
\pm 1 \cdot 8\end{array}$ & $\begin{array}{r}32 \cdot 0 \\
\pm 2 \cdot 7\end{array}$ & $\begin{array}{r}70 \\
+29\end{array}$ & $\begin{array}{r}93 \\
+38\end{array}$ & $\begin{array}{r}86 \\
\pm 21\end{array}$ & $\begin{array}{r}60 \\
\pm 27\end{array}$ & $\begin{array}{r}29 \\
\pm 19\end{array}$ & $\begin{array}{r}37 \\
\pm 23\end{array}$ & & & & & & \\
\hline $\begin{array}{l}27 \cdot 4 \\
32 \cdot 7 \\
27 \cdot 3 \\
28 \cdot 2 \\
29 \cdot 5 \\
28 \cdot 0 \\
30 \cdot 3 \\
31 \cdot 5 \\
28 \cdot 0 \\
31 \cdot 6 \\
31 \cdot 4 \\
27 \cdot 7 \\
29 \cdot 0 \\
30 \cdot 8 \\
31 \cdot 6 \\
33 \cdot 5 \\
29 \cdot 8 \\
29 \cdot 1 \\
30.8 \\
33 \cdot 5\end{array}$ & $\begin{array}{c}28 \cdot 2 \\
33.8 \\
31 \cdot 6 \\
32.6 \\
25 \cdot 4 \\
29 \cdot 3 \\
31 \cdot 0 \\
31 \cdot 8 \\
29 \cdot 2 \\
28 \cdot 2 \\
30 \cdot 0 \\
30.9 \\
30.8 \\
31.4 \\
29.8 \\
29.8 \\
31.2 \\
31.6\end{array}$ & $\begin{array}{l}28 \cdot 2 \\
30.8 \\
32.9 \\
27.2 \\
32.0 \\
31.0 \\
29.8 \\
33.5 \\
33.9 \\
33.1 \\
32.6 \\
31.7 \\
33.0 \\
31.0 \\
34.4 \\
33.6 \\
30.4 \\
31 \cdot 2 \\
33.1 \\
32.4\end{array}$ & $\begin{array}{r}63 \\
78 \\
100 \\
116 \\
100 \\
88 \\
58 \\
49 \\
35 \\
94 \\
135 \\
109 \\
66 \\
119 \\
82 \\
42 \\
100 \\
62 \\
49 \\
65\end{array}$ & $\begin{array}{l}58 \\
62 \\
\\
79 \\
45 \\
59 \\
\\
49 \\
66 \\
67 \\
83 \\
70 \\
89 \\
63 \\
85 \\
52 \\
35 \\
44 \\
68\end{array}$ & $\begin{array}{l}42 \\
19 \\
87 \\
69 \\
47 \\
53 \\
59 \\
32 \\
75 \\
62 \\
77 \\
90 \\
54 \\
96 \\
74 \\
56 \\
70 \\
39 \\
39 \\
61\end{array}$ & $\begin{array}{l}56 \\
36 \\
41 \\
72 \\
54 \\
25 \\
37 \\
15 \\
92 \\
28 \\
44 \\
30 \\
30 \\
56 \\
47 \\
43 \\
54 \\
30 \\
71 \\
94\end{array}$ & $\begin{array}{r}42 \\
14 \\
15 \\
60 \\
36 \\
48 \\
70 \\
15 \\
91 \\
40 \\
68 \\
29 \\
39 \\
69 \\
21 \\
43 \\
21 \\
84 \\
80 \\
100\end{array}$ & $\begin{array}{r}7 \\
21 \\
69 \\
43 \\
41 \\
41 \\
52 \\
13 \\
93 \\
35 \\
\\
24 \\
55 \\
73 \\
25 \\
52 \\
40 \\
81 \\
96 \\
45\end{array}$ & $\begin{array}{c}\text { III } \\
\text { III } \\
\text { II } \\
\text { II } \\
\text { II } \\
\text { III } \\
\text { II } \\
\text { III } \\
\text { IV } \\
\text { II } \\
\text { III } \\
\text { II } \\
\text { III } \\
\text { III } \\
\text { II } \\
\text { II } \\
\text { III } \\
\text { III } \\
\text { IV } \\
\text { II }\end{array}$ & $\begin{array}{r}\text { II } \\
\text { II } \\
\text { II } \\
\text { II } \\
\text { II } \\
\text { III } \\
\text { II } \\
\text { III } \\
\text { III } \\
\text { II } \\
\text { II } \\
\text { II } \\
\text { III } \\
\text { III } \\
\text { II } \\
\text { II } \\
\text { III } \\
\text { III } \\
\text { III } \\
\text { II }\end{array}$ & $\begin{array}{r}\text { II } \\
\text { II } \\
\text { II } \\
\text { II } \\
\text { II } \\
\text { III } \\
\text { II } \\
\text { III } \\
\text { III } \\
\text { II } \\
\text { II } \\
\text { II } \\
\text { III } \\
\text { III } \\
\text { II } \\
\text { II } \\
\text { III } \\
\text { II } \\
\text { III } \\
\text { II }\end{array}$ & $\begin{array}{l}3 \\
2 \\
2 \\
2 \\
2 \\
2 \\
2 \\
2 \\
2 \\
2 \\
2 \\
2 \\
2 \\
2 \\
2 \\
2 \\
2 \\
2 \\
3 \\
3\end{array}$ & $\begin{array}{l}2 \\
2 \\
2 \\
2 \\
2 \\
2 \\
2 \\
2 \\
2 \\
2 \\
2 \\
2 \\
2 \\
2 \\
2 \\
2 \\
2 \\
2 \\
2\end{array}$ & $\begin{array}{l}1 \\
2 \\
2 \\
2 \\
2 \\
2 \\
2 \\
2 \\
2 \\
2 \\
2 \\
2 \\
2 \\
2 \\
2 \\
2 \\
2 \\
2 \\
3 \\
1\end{array}$ \\
\hline $\begin{array}{r}30 \cdot 1 \\
\pm 1 \cdot 7\end{array}$ & $\begin{array}{r}30 \cdot 4 \\
\pm 1 \cdot 2\end{array}$ & $\begin{array}{r}31 \cdot 8 \\
\pm 0.9\end{array}$ & $\begin{array}{r}80 \\
\pm 28\end{array}$ & $\begin{array}{r}63 \\
\pm 16\end{array}$ & $\begin{array}{r}60 \\
\pm 20\end{array}$ & $\begin{array}{r}50 \\
\pm 15\end{array}$ & $\begin{array}{r}49 \\
\pm 27\end{array}$ & $\begin{array}{r}46 \\
\pm 21\end{array}$ & & & & & & \\
\hline
\end{tabular}


Critical Study of the Focal-Sepsis Theory of Rheumatic Disease. (Kritisches zur Fokallehre rheumatischer Erkrankungen.) ScHмID, J. (1958). Klin. Med. (Wien), 18, 370. 6 figs.
Rheumatoid Syndromes in the Malignant Blood Diseases. (Síndromes reumatoideos en las hemopatías malignas.) Etcheverry B, R., Guzmán L, C., Regonesi L, C., Muranda R, M., and Losada L, M. (1958). Arch. argent. Reum., 21, 96.11 refs.

\section{CORRIGENDA}

In the article by J. Richmond, L. M. H. Roy, D. L. Gardner, W. R. M. Alexander, and J. J. R. Duthie, entitled "Nature of Anaemia in Rheumatoid Arthritis. IV" (Annals, 1958, 17, 406):

p. 408 , col. $1,1.6$ : the haemoglobin standard should read $14 \cdot 8 \mathrm{~g} . / 100 \mathrm{ml}$. and not $14 \cdot 3$. p. 411, Table VIII: the iron content of bone marrow, as measured by the chemical method (cols 4 and 5), should be stated in $\mathrm{mg} . / 100 \mathrm{mg}$. protein and not in $\mathrm{mg} . / \mathrm{g}$. 